\title{
ASAS KEBEBASAN BERKONTRAK DALAM PERJANJIAN KERJA TENAGA KERJA ASING DIKAITKAN DENGAN UNDANG-UNDANG NOMOR 13 TAHUN 2003 TENTANG KETENAGAKERJAAN
}

\section{The Principle Of Freedom Of Contract In Foreign Labor Agreement Related With Regulation Number 13 Years 2003 About Employment}

\author{
Taun Taun ${ }^{1}$ \\ Fakultas Hukum Universitas Singaperbangsa Karawang \\ Alamat : Jl. H.S. Ronggowaluyo, Puseurjaya, Telukjambe Timur-Karawang, Jawa Barat \\ Kode Pos 41361 E-mail: taun@fh.unsika.ac.id
}

\begin{abstract}
ABSTRAK
Asas kebebasan berkontrak merupakan asas dalam membuat perjanjian, yang berarti setiap orang bebas untuk mengadakan suatu perjanjian yang memuat syarat-syarat perjanjian macam apapun, sepanjang perjanjian itu dibuat secara sah dan beritikad baik, serta tidak melanggar ketertiban umum dan kesusilaan. Sehingga yang perlu diperhatikan adalah syarat sah perjanjian Pasal 1320 KUHPerdata, salah satinya adalah sebab yang halal, artinya tidak bertentangan dengan ketertiban umum, kesusilaan dan perundang-undangan, dalam membuat perjanjian tenaga kerja asing undangundangnya diatur dalam Undang-Undang Ketenagakerjaan, sehingga rumusan masalahnya yaitu sejauhmana luas asas kebebasan berkontrak dan seberapa jauh negara dapat campur tangan dalam menentukan isi suatu perjanjian.

Menggunakan pendekatan yuridis normatif, Pendekatan penelitian yang digunakan dalam penelitian hukum ini yakni meliputi Pendekatan Perundang-undangan yaitu Kitab Undang-Undang Hukum Perdata dan Undang-Undang Ketenagakerjaan dan Pendekatan Konsep yaitu konsep asas kebebasan berkontrak.

Penerapan asas kebebasan berkontrak dalam membuat perjanjian tenaga kerja asing dapat diterapkan, artinya para pihak dapat membuat bebas isi klausul perjanjian kerja selama memperhatikan syarat sah perjanjian Pasal 1320 KUHPerdata yaitu sepakat, cakap, hal tertentu dan sebab yang halal, sebab yang halal artinya tidak bertentangan dengan ketertiban umum, kesusilaan dan perundang-undangan, yakni Undang-Undang ketenagakerjaan, serta negara dapat campur tangan dalam menentukan isi perjanjian tersebut melalui perundang-undangan.
\end{abstract}

Kata kunci : Asas Kebebasan Berkontrak; Tenaga Kerja Asing; Perjanjian Kerja Waktu Tertentu.

\section{ABSTRACT}

The principle of freedom of contract is a principle of making a covenant, which means that everyone is free to enter into an agreement containing the terms of any kind of agreement, as long as it is made lawfully and in good faith, and does not violate public order and decency. So that the right to note is the legal condition of article 1320 of the Civil Code, one of which is a halal reason, meaning it does not conflict with public order, decency and legislation, in making foreign labor 
agreements legally regulated in the Employment Law, so that the formulation of the problem is the extent of the principle of freedom of contract and how far the country can intervene in determining the content of an agreement.

Using a normative juridical approach, the research approach used in this legal research includes the Statutory Approach, namely civil law and employment law and concept approach, which is the principle concept of freedom of contract.

The application of the principle of freedom of contract in making foreign labor agreements can be applied, meaning that the parties can make free the contents of the clauses of the employment agreement as long as it takes into account the legal terms of article 1320 of the Code of Data i.e. agree, capable, certain things and halal causes, because the halal means not to conflict with the public order, decency and legislation, namely employment law, and the state can intervene in determining the content of the agreement through legislation.

Keywords: Principle of Freedom of Contract; Foreign workers; Specific Time Work Agreement.

\section{PENDAHULUAN}

A. Latar Belakang

Masyarakat Ekonomi ASEAN sudah berlaku sejak 31 Desember 2015, termasuk Indonesia, sudah resmi melaksanakan komitmen bersama yang bernama Masyarakat Ekonomi Asean (MEA). Sehingga Indonesia harus siap bersaing dengan negara lain, salah satunya tenaga kerja indonesia yang harus bisa bersaing dengan tenaga kerja asing. Selain itu Indonesia juga harus kuat dari segi regulasi dalam menerima serbuan tenaga kerja asing yang datang ke Indonesia. ${ }^{1}$

Undang-Undang Nomor 13 Tahun 2003 tentang Ketenagakerjaan menjadi pilar utama yang mengatur tenaga kerja asing terutama di Bab VIII mulai Pasal 42 sampai dengan Pasal 49. Yang harus menjadi perhatian adalah Pasal 45 ayat (1a) yang mewajibkan adanya tenaga kerja warga negara Indonesia yang menjadi pendamping tenaga kerja asing yang dipekerjakan untuk alih teknologi dan alih keahlian dari tenaga kerja asing tersebut. Kehadiran tenaga kerja asing di era MEA ini tidak lagi dalam konteks alih pengetahuan (transfer of knowledge) dan alih tehnologi (transfer of technology), tetapi tenaga kerja asing hadir dengan dengan semangat integrasi ekonomi ASEAN. Atau dengan kata lain kebebasan bekerja dimanapun tenaga kerja asing tersebut ingin bekerja. Pengaturan hubungan kerja antara pengusaha dengan tenaga kerja asing merupakan benteng utama dalam membina hubungan yang harmonis antara pengusaha dengan tenaga kerja asing, Hubungan kerja tersebut ada 3 unsur/faktor yang menentukan adanya hubungan kerja, yaitu: adanya pekerjaan yang harus dilakukan, adanya perintah (bekerja atas perintah

\footnotetext{
1 Anis Tiana Pottag, Politik Hukum Pengendalian Tenaga Kerja Asing Yang Bekerja Di Indonesia, Media Iurius, Vol. 1 No. 2 (2018): 236-237.
} 
ISSN (Print): 2085-8477; ISSN (Online): 2655-4348

atasan/pengusaha); dan adanya upah oleh karenanya tenaga kerja asing di Indonesia harus ada dalam hubungan kerja sebab tanpa adanya salah satu unsur dari ketiga unsur tersebut maka tidak ada hubungan kerja. ${ }^{2}$ Salah satunya diatur dalam Pasal 42 ayat (4) UndangUndang Nomor 13 Tahun 2003 tentang Ketenagakerjaan, yang berbunyi: “Tenaga kerja asing dapat dipekerjakan di Indonesia hanya dalam hubungan kerja untuk jabatan tertentu dan waktu tertentu." Dalam setiap perjanjian tentu ada prestasi yang harus dilakukan, maka dalam hal perjanjian kerja ini kewajiban pengusaha adalah suatu prestasi yang harus dilakukan oleh pengusha bagi kepentingan tenaga kerjanya yaitu kewajiban membayar upah, Kewajiban untuk memberikan waktu istirahat dan cuti tahunan dan kewajiban mengurus perawatan dan pengobatan. ${ }^{3}$

Tenaga kerja asing tidak bisa dipekerjakan dengan status karyawan tetap atau perjanjian kerja waktu tidak tertentu, dan hanya bisa dipekerjakan dengan status karyawan kontrak atau perjanjian kerja waktu tertentu sehingga pengaturan masa kerja perjanjian kerja waktu tertentu seorang tenaga kerja asing di Indonesia mengacu kepada Pasal 59 Undang-Undang Nomor 13 Tahun 2003 tentang Ketenagakerjaan yang mengatur masa kerja perjanjian kerja waktu tertentu diadakan paling lama 2 (dua) tahun, dapat dilakukan perpanjangan 1 (satu) kali dengan waktu paling lama 1(stau) tahun dan dapat dilakukan pembaharuan 1 (satu) kali dengan waktu paling lama 2 (dua) tahun. Sehingga yang tertuang dalam Pasal 59 tersebut jika perusahaan yang mempekerjakan TKA maksimal 5 tahun dengan perpanjangan dan pembaharuan yang maksimal, atau bisa kurang dari 5 tahun sesuai kebijakan perusahaan. Namun yang menjadi masalah adalah ketika perusahaan melakukan pelanggaran terhadap Pasal 59 tersebut, yaitu jika mempekerjakan tenaga kerja asing lebih dari 5 (lima) tahun, maka menurut Pasal 59 ayat (7) Undang-Undang Nomor 13 Tahun 2003 tentang Ketenagakerjaan: "Perjanjian kerja untuk waktu tertentu yang tidak memenuhi ketentuan sebagaimana dimaksud dalam ayat (1), ayat (2), ayat (4), ayat (5) dan ayat (6) maka demi hukum menjadi penjanjian kerja waktu tidak tertentu." Artinya tenaga kerja asing tersebut berubah statusnya demi hukum dari karyawan kontrak (perjanjian kerja waktu tertentu) menjadi karyawan tetap (perjanjian kerja waktu tidak tertentu), namun hal ini berbenturan dengan Pasal 42 ayat (4) Undang-Undang Nomor 13 Tahun 2003 tentang Ketenagakerjaan, yaitu tenaga kerja asing hanya bisa dipekerjakan dengan status karyawan kontrak (perjanjian kerja waktu

\footnotetext{
${ }^{2}$ Aries Harianto, Hukum Ketenagakerjaan Makna Kesusilaan dalam Perjanjian Kerja, (Yogyakata: Lakbang PRESSindo, 2016), 194.

${ }^{3}$ Danang Sunyoto, Hak dan Kewajiban bagi Pekerja dan Pengusaha, (Jakarta: Pustaka Yustisia, 2013$), 43$.
} 
tertentu), yang pada akhirnya hal ini menimbulkan ketidakpastian hukum, perusahaan bisa mempekerjakan tenaga kerja asing dengan status karyawan kontrak, namun masa kerja tenaga kerja asing tersebut tidak bisa dibatasi. Serta jika dilihat dari pengaturan perjanjian secara umum, terdapat asas kebebasan berkontrak yang dituangkan dalam Pasal 1338 ayat (1) KUHPerdata, yang menyatakan bahwa semua kotrak/perjanjian yang dibuat secara sah berlaku sebagai undang-undang bagi mereka yang membuatnya, ${ }^{4}$ artinya para pihak yang melakukan perjanjian dapat bebas mengatur isi dari perjanjian tersebut, namun dalam perjanjian kerja tenaga kerja asing ini negara ikut campur dalam mengatur isi dari perjanjian itu melalui Undang-Undang Nomor 13 Tahun 2003 tentang Ketenagakerjaan.

\section{B. Rumusan Masalah}

Permasalahan yang akan dikaji dalam penelitian ini yakni berkaitan dengan seberapa jauh negara dapat campur tangan dalam menentukan isi suatu perjanjian?

\section{Metode}

Rancangan ini menggunakan pendekatan yuridis normatif, yaitu jenis pendekatan yang mengkaji atau menganalisis data sekunder seperti bahan pustaka atau data sekunder yang terdiri dari bahan hukum primer, bahan hukum sekunder dan bahan hukum tersier. Bahanbahan tersebut disusun secara sistematis, dikaji kemudian dibandingkan dan ditarik kesimpulan dalam hubungannya dengan masalah yang diteliti. Pendekatan penelitian yang digunakan dalam penelitian hukum ini yakni meliputi Statute Approach (Pendekatan Perundang-undangan) dan Conceptual Approach (Pendekatan Konsep). Pendekatan Konsep atau Conceptual Approach dilakukan untuk mempelajari konsep-konsep terkait dengan asas kebebasan berkontrak dan perjanjian kerja waktu tertentu yang juga menjadi fokus dalam isu hukum terkait tema penelitian. Pendekatan Perundang-undangan atau Statute Approach ialah pendekatan dengan menggunakan legislasi dan regulasi. ${ }^{5}$ Dalam penelitian ini pendekatan dilakukan dengan menelaah peraturan perundang-undangan maupun hukum positif yang berlaku di negara Indonesia khususnya yang berkaitan dengan hukum perikatan dan hukum ketenagakerjaan yang juga menjadi fokus dalam isu hukum terkait tema penelitian.

\footnotetext{
${ }^{4}$ Muhammad Noor, "Penerapan Prinsip-Prinsip Hukum Perikatan Dalam Pembuatan Kontrak", Mazahib Jurnal Pemikiran Hukum Islam, Vol. XIV No. 1 (2015): 89-91.

5 Johnny Ibrahim, Teori dan Metodologi Penelitian Hukum Normatif, (Malang: Bayumedia Publishing, 2007), 57.
} 
ISSN (Print): 2085-8477; ISSN (Online): 2655-4348

Bahan hukum yang digunakan dalam penelitian ini adalah bahan hukum primer yaitu bahan hukum yang bersifat autoritatif artinya mempunyai otoritas, terdiri dari perundangundangan, risalah pembuatan perundang-undangan dan putusan-putusan hakim. ${ }^{6}$ Bahan hukum primer dalam karya tulis ini meliputi: 1) Kitab Undang-Undang Hukum Perdata; 2) Undang-Undang Nomor 13 Tahun 2003 tentang Ketenagakerjaan; Bahan hukum sekunder, yaitu buku teks karena buku teks berisi prinsip-prinsip dasar ilmu hukum dan pandanganpandangan klasik para sarjana yang mempunyai kualifikasi tinggi. ${ }^{7}$ Literatur-literatur yang terkait permasalahan inilah yang masuk kualifikasi bahan hukum sekunder yang terkait permasalahan yang dikaji, antara lain: 1) Buku-buku hasil penelitian; 2) Pendapat dan doktrin para sarjana.Bahan hukum tersier, yaitu bahan hukum yang memberikan penjelasan bahan hukum primer dan sekunder terutama mengenai istilah-istilah, yang terdiri dari :1) Kamus Hukum; 2) Kamus Besar Bahasa Indonesia; 3) Kamus Terjemahan Inggris-Indonesia.

\section{Tinjauan Pustaka}

\section{Asas Kebebasan Berkontrak}

Asas Kebebasan berkontrak terdapat dalam pasal 1338 ayat (1) KUHPerdata. Kebebasan dalam membuat perjanjian dimana para pihak dapat dengan bebas mengatur hak dan kewajiban dalam perjanjian yang disepakati. Menurut Subekti dalam Bukunya Hukum Perjanjian, Asas Kebebasan berkontrak adalah suatu asas yang menyatakan bahwa setiap orang pada dasarnya boleh membuat kontrak (perjanjian) yang berisi dan macam apapun asal tidak bertentangan dengan undang-undang, kesusilaan dan keteriban umum. ${ }^{8}$ Kebebasan berkontrak bukan berarti para pihak dapat membuat kontrak (perjanjian) secara bebas, akan tetapi tetap mengindahkan syarat-syarat sahnya pernjanjian, baik syarat umum sebagaimana yang ditentukan oleh pasal 1320 KUHPerdata, maupun syarat khusus untuk perjanjianperjanjian tertentu. Keberadaan asas kebebasan berkontrak ini tentu saja bukan berarti kebebasan tanpa batas. Bahwa asas kebebasan berkontrak tetap dibatasi, yang pelaksanaannya tidak boleh bertentangan dengan ketertiban umum atau public policy yang berlaku di wilayah tersebut.

Adapun maksud dari asas kebebasan berkontrak ini yakni, memberikan kebebasan kepada pihak-pihak untuk pertama, membuat atau tidak membuat perjanjian; kedua,

\footnotetext{
${ }^{6}$ Ibid. Hal 51

${ }^{7}$ Ibid Hal. 52

${ }^{8}$ Subekti, Pokok-Pokok Hukum Perdata,Cet. ke-XXXIII, PT.Intermasa, Jakarta 2005,Hal.13
} 
mengadakan perjanjian dengan siapapun; ketiga menentukan isi perjanjian, pelaksanaan, dan persyaratannya; keempat menentukan bentuknya perjanjian, yaitu tertulis atau lisan. ${ }^{9}$

\section{Tenaga Kerja Asing}

Secara yuridis, berdasarkan undang-undang ketenagakerjaan makna dari tenaga kerja asing adalah warga negara asing pemegang visa dengan maksud bekerja di Indonesia. Penggunaan tenaga kerja asing oleh suatu negara tentu perlu diperhatikan oleh para pengusaha atau pelaku usaha. Berdaraskan ketentuannya dinyatakan bahwa setiap pemberi kerja yang mempekerjakan tenaga kerja asing wajib memiliki izin tertulis dari Menteri atau pejabat yang ditunjuk. Untuk memberikan kesempatan kerja yang lebih luas kepada tenaga kerja Indonesia (TKI), pemerintah membatasi penggunaan tenaga kerja asing dan melakukan pengawasan.

Keberadaan tenaga kerja asing dapat dikatakan sebagai salah satu pembawa devisa bagi negara dimana adanya pembayaran kompensasi atas setiap tenaga kerja asing yang dipekerjakan, tentu saja ini membawa keuntungan bagi negara. Di Indonesia sendiri, berdasarkan aturannya sangat memungkinkan untuk menggunakan tenaga kerja asing, namun tentunya harus sesuai dengan syarat-syarat yang telah ditentukan dalam undang-undang ketenagakerjaan yang berlaku.

\section{PEMBAHASAN}

\section{A. Luas Asas Kebebasan Berkontrak}

Dalam kehidupan manusia tentu tidak lepas dengan adanya hubungan antara manusia satu dengan yang lainnya, hubungan antara manusia satu dengan yang lainnya tersebut dalam istilah hukum dikenal dengan perikatan yang diatur dalam hukum perikatan. Secara umum hukum perikatan diatur dalam buku III KUHPerdata, ikatan manusia satu dengan yang lainnya bisa timbul karena adanya perjanjian maupun karena adanya undang-undang, sebagaimana diatur dalam Pasal 1233 KUHPerdata yaitu: "Perikatan lahir karena suatu persetujuan atau karena undang-undang". ${ }^{10}$ Perjanjian adalah salah satu sumber timbulnya perikatan selain undang-undang, perjanjian pada umumnya diatur dalam Pasal 1313 KUHPerdata yaitu : "suatu perjanjian adalah suatu perbuatan dimana satu orang atau lebih mengikatkan dirinya terhadap satu orang atau lebih". Dalam membuat suatu perjanjian selain

\footnotetext{
${ }^{9}$ H.S. Salim. 2006,Hukum Kontrak, Teori dan Teknik Penyusunan Kontrak. Cetakan Ketiga. Sinar Grafika. Jakarta

${ }^{10}$ Maria Anggita Dian Pramestie, Jamal Wiwoho, "Implementasi Asas Kebeasan Berkontrak Dalam Perjanjian Pemberian Kredit", Jural Repertorium Vol. IV No. 2, (2017): 110-111.
} 
harus memperhatikan buku III KUHPerdata, harus juga diperhatikan asas-asas dalam perjanjian dan bila diperlukan aturan perundang-undangan yang lain yang mengatur secara khusus perjanjian tertentu. Salah satu asas hukum yang dianut dalam hukum perjanjian adalah "asas kebebasan berkontrak", yang berarti setiap orang bebas untuk mengadakan suatu perjanjian yang memuat syarat-syarat perjanjian macam apapun, sepanjang perjanjian itu dibuat secara sah dan beritikad baik, serta tidak melanggar ketertiban umum dan kesusilaan. ${ }^{11}$ Kebebasan ini adalah perwujudan dari kehendak bebas, pancaran hak dan hak asasi manusia. $^{12}$

Kebebasan berkontrak merupakan salah satu asas penting dalam hukum perjanjian. Pada abad kesembilan belas, kebebasan berkontrak sangat diagungkan dan mendominasi. Keberadaan asas kebebasan berkontrak tidak dapat dilepaskan dari pengaruh aliran filsafat ekonomi liberal. Di mana dalam bidang ekonomi berkembang aliran Laissez Faire, yang dipelopori oleh Adam Smith yang menekankan kepada prinsip non intervensi pemerintah dalam kegiatan ekonomi dan bekerjanya pasar. $^{13}$

Dalam KUHPerdata maupun dalam peraturan perundangan lainnya, tidak ada satu pasalpun yang menyatakan dengan tegas berlakunya asas kebebasan berkontrak. Mengenai keberadaan asas kebebasan berkontrak tersebut, dari beberapa pasal KUHPerdata, yaitu Pasal 1329 KUHPerdata yang menentukan bahwa "setiap orang cakap untuk membuat perjanjian, kecuali jika ia ditentukan tidak cakap oleh undang-undang." Dari ketentuan Pasal 1332 KUHPerdata dapat disimpulkan bahwa "asalkan menyangkut barang-barang yang bernilai ekonomis, maka setiap orang bebas untuk memperjanjikanya.” Dari Pasal 1320 ayat (4) Jo. Pasal 1337 KUHPerdata dapat disimpulkan bahwa "asalkan bukan mengenai kausa yang dilarang oleh undang-undang atau bertentangan dengan kesusilaan baik atau ketertiban umum, maka setiap orang bebas untuk memperjanjikannya."14 Pasal 1338 Ayat (1) KUHPerdata yang menyatakan bahwa "Semua perjanjian yang dibuat secara sah berlaku sebagai undang-undang bagi yang membuatnya." Dapat ditafsirkan bahwa setiap orang dapat membuat perjanjian dengan isi apapun, ada kebebasan setiap subyek hukum untuk membuat perjanjian dengan siapapun yang dikehendaki, dengan isi dan bentuk yang dikehendaki. ${ }^{15}$

11 Dedi Harianto, “Asas Kebebasan Berkontrak: Problematika Penerapannya Dalam Kontrak Baku Antara Konsumen Dengan Pelaku Usaha”, Jurnal Hukum Samudra Keadilan, Vol. II Nomor 2 (2016): 145-149.

12 Ibid

13 Ridwan Khairandy, Itikad Baik Dalam Kebebasan Berkontrak, (Jakarta: Fakultas Program Pascasarjana Fakultas Hukum Universitas Indonesia, 2003), 234.

${ }^{14}$ Dedi Harianto, Op. Cit. 149

15 Ibid 
Penjabaran lebih lanjut asas kebebasan berkontrak menurut hukum perjanjian Indonesia meliputi ruang lingkup sebagai berikut $:{ }^{16}$

1. Kebebasan untuk membuat atau tidak membuat perjanjian;

2. Kebebasan untuk memilih pihak dengan siapa akan membuat perjanjian;

3. Kebebasan untuk menentukan atau memilih kausa dari perjanjian yang dibuatnya;

4. Kebebasan untuk menentukan obyek perjanjian;

5. Kebebasan untuk syarat-syarat suatu perjanjian, termasuk kebebasan untuk menerima atau menyimpangi ketentuan undang-undang yang bersifat opsional (aanvullend, optional).

Kebebasan berkotrak tentu saja bukan bebas tanpa adanya batasan, kebebasan tersebut harus tetap memperhatikan syarat sah perjanjian Pasal 1320 KUHPerdata, baik itu dari subjek yang melakukan perjanjian yang harus sudah cakap hukum dan berwenang melakukan perjanjian, maupun objek dalam perjanjian tersebut tidak boleh bertentangan dengan undangundang, kesusilaan dan ketertiban umum.

\section{B. Campur Tangan Negara dalam Menentukan Isi Perjanjian Kerja Tenaga Kerja Asing}

Ruang lingkup perjanjian sendiri sangat luas salah satunya jika dikaitkan dengan hukum ketenagakerjaan yang diatur dalam Undang-Undang No. 13 Tahun 2003 tentang Ketenagakerjaan, dalam hukum ketenagakerjaan salah satu pengaturannya adalah hubungan kerja antara pekerja dengan pemberi kerja/ pengusaha. Hubungan kerja tersebut diatur dalam perjanjian kerja yang syaratnya diatur dalam Pasal 52 ayat (1) Undang-Undang No. 13 Tahun 2003 tentang Ketenagakerjaan, yaitu sebagai berikut: ${ }^{17}$

Perjanjian kerja dibuat atas dasar :

a. kesepakatan kedua belah pihak;

b. kemampuan atau kecakapan melakukan perbuatan hukum;

c. adanya pekerjaan yang diperjanjikan; dan

d. pekerjaan yang diperjanjikan tidak bertentangan dengan ketertiban umum, kesusilaan dan peraturan perundang-undangan yang berlaku.

Pada dasarnya syarat perjanjian kerja tersebut sama dengan syarat sah perjanjian pada umumnya sesuai yang diatur dalam Pasal 1320 KUHPerdata, namun dalam perjanjian kerja dalam hukum ketenagakerjaan dapat dibagi menjadi dua, yaitu perjanjian kerja waktu tertentu

\footnotetext{
${ }^{16}$ Ibid

17 Gios Adhyaksa, "Penerapan Asas Perlindungan Yang Seimbang Menurut Kuhperdata Dalam Pelaksanaan Perjanjian Kerja Untuk Waktu Tertentu Dihubungkan Dengan Undang-Undang Nomor 13 Tahun 2003 Tentang Ketenagakerjaan”, Jurnal Unifikasi,Vol. 3 No. 2 (2016): 77-81.
} 
ISSN (Print): 2085-8477; ISSN (Online): 2655-4348

dan perjanjian kerja waktu tidak tertentu, hal tersebut diatur dalam Pasal 56 Undang-Undang No. 13 Tahun 2003 tentang Ketenagakerjaan, dengan dibedakannya jenis perjanjian kerja tersebut maka syarat yang lebih khusus untuk perjanjian kerja waktu tertentu dengan perjanjian kerja waktu tidak tertentu dibedakan.

Pengaturan khusus terkait perjanjian kerja waktu tidak tertentu yaitu diatur dalam Pasal 60 ayat (1) Undang-Undang No. 13 Tahun 2003 tentang Ketenagakerjaan, yaitu dalam perjanjian kerja waktu tidak tertentu dapat mensyaratkan masa percobaan kerja paling lama 3 (tiga) bulan. Adapun pengaturan tentang perjanjian kerja waktu tertentu pengaturannya sedikit lebih rumit, yaitu sebagaimana diatur dalam Pasal 59 Undang-Undang No. 13 Tahun 2003 tentang Ketenagakerjaan: ${ }^{18}$

(1) Perjanjian kerja untuk waktu tertentu hanya dapat dibuat untuk pekerjaan tertentu yang menurut jenis dan sifat atau kegiatan pekerjaannya akan selesai dalam waktu tertentu, yaitu :

a. pekerjaan yang sekali selesai atau yang sementara sifatnya;

b. pekerjaan yang diperkirakan penyelesaiannya dalam waktu yang tidak terlalu lama dan paling lama 3 (tiga) tahun;

c. pekerjaan yang bersifat musiman; atau

d. pekerjaan yang berhubungan dengan produk baru, kegiatan baru, atau produk tambahan yang masih dalam percobaan atau penjajakan.

(2) Perjanjian kerja untuk waktu tertentu tidak dapat diadakan untuk pekerjaan yang bersifat tetap.

(3) Perjanjuan kerja untuk waktu tertentu dapat diperpanjang atau diperbaharui.

(4) Perjanjian kerja waktu tertentu yang didasarkan atas jangka waktu tertentu dapat diadakan untuk paling lama 2 (dua) tahun dan hanya boleh diperpanjang 1 (satu) kali untuk jangka waktu paling lama 1 (satu) tahun.

(5) Pengusaha yang bermaksud memperpanjang perjanjian kerja waktu tertentu tersebut, paling lama 7 (tujuh) hari sebelum perjanjian kerja waktu tertentu berakhir telah memberitahukan maksudnya secara tertulis kepada pekerja/buruh yang bersangkutan.

(6) Pembaruan perjanjian kerja waktu tertentu hanya dapat diadakan setelah melebihi masa tenggang waktu 30 (tiga puluh) hari berakhirnya perjanjian kerja

\footnotetext{
${ }^{18}$ Falentino Tampongangoy, "Penerapan Sistem Perjanjian Kerja Waktu Tertentu Di Indonesia “,Lex Privatum Vol. I No. 1 (2013): 146-154.
} 
waktu tertentu yang lama, pembaharuan perjanjian kerja waktu tertentu ini hanya boleh dilakukan 1 (satu) kali dan paling lama 2 (dua) tahun.

(7) Perjanjian kerja untuk waktu tertentu yang tidak memenuhi ketentuan sebagaimana dimaksud dalam ayat (1), ayat (2), ayat (4), ayat (5) dan ayat (6) maka demi hukum menjadi penjanjian kerja waktu tidak tertentu.

(8) Hal-hal lain yang belum diatur dalam Pasal ini akan diatur lebih lanjut dengan Keputusan Menteri.

Dalam hal ini sudah jelas, jika perusahaan ingin mempekerjakan pekerja dengan sistem perjanjian kerja waktu tertentu maka pekerjaan tersebut akan slesai dalam waktu tertentu, baik dari segi sifat pekerjaannya atau waktu penyelesaiannya, maka ketika sifat pekerjaan tersebut dibutuhkan selamanya dalam suatu perusahaan maka tidak bisa menggunakan sistem perjanjian kerja waktu tertentu. ketika perusahaan mempekerjakan pekerja dengan sistem perjanjian kerja waktu tertentu, maka Batasan waktunya yaitu paling lama 2 (dua) tahun, perpanjangann 1 (satu) tahun, dan pembaharuan kontrak selama maksimal 2 (dua) tahun. ketika perusahaan melanggar hal-hal tersebut maka status pekerja tersebut berubah menjadi perjanjian kerja waktu tidak tertentu (karyawan tetap).

Dalam hukum ketenagakerjaan dimungkinkan juga untuk mempekerjakan tenaga kerja asing, dengan persyaratan-persyaratan tertentu sesuai yang diatur dalam undangundang, penggunaan tenaga kerja asing diatur dalam bab VIII tentang penggunaan tenaga kerja asing Undang-Undang Nomor 13 Tahun 2003 tentang Ketenagakerjaan. Salah satu syarat perusahaan dapat mempekerjakan tenaga kerja asing yaitu tenaga kerja asing hanya dapat dipekerjakan dalam hubungan kerja untuk jabatan tertentu dan waktu tertentu, hal tersebut diatur dalam Pasal 42 ayat (4) Undang-Undang Nomor 13 Tahun 2003 tentang Ketenagakerjaan, yang berbunyi: ${ }^{19}$

"Tenaga kerja asing dapat dipekerjakan di Indonesia hanya dalam hubungan kerja untuk jabatan tertentu dan waktu tertentu".

Menurut pasal diatas, tenaga kerja asing tidak boleh dipekerjakan dengan status perjanjian kerja waktu tidak tertentu atau biasa disebut dengan karyawan tetap, dan hanya boleh dipekerjakan dengan status perjanjian kerja waktu tertentu atau biasa disebut dengan karyawan kontrak. Maka pengaturan perjanjian kerja tenaga kerja asing didasarkan pada pengaturan perjanjian kerja waktu tertentu, yaitu dalam membuat perjanjian kerja waktu tertentu harus dibuat secara tertulis dan menggunakan bahasa Indonesia dan huruf latin, hal

${ }_{19}$ Risky Vista Puspita Sari, Aries Harianto, Ida Bagus Oka Ana, "Kepastian Hukum Pengaturan Penggunaan Tenaga Kerja Asing di Indonesia”, Lentera Hukum Vol. 5 Issue 3 (2018): 368-374. 
ISSN (Print): 2085-8477; ISSN (Online): 2655-4348

tersebut sesuai dalam Pasal 57 ayat (1) Undang-Undang No. 13 Tahun 2003 tentang Ketenagakerjaan, kemudian pengaturan kaitan dengan jangka waktunya diatur dalam Pasal 59 Undang-Undang No. 13 Tahun 2003 tentang Ketenagakerjaan seperti dalam pembahasan diatas, yaitu yang menjadi syaratnya adalah sebagai berikut:

1. Pekerjaan yang jenis dan sifat atau kegiatannya akan selesai dalam waktu tertentu, yaitu:

a. pekerjaan yang sekali selesai atau yang sementara sifatnya;

b. pekerjaan yang diperkirakan penyelesaiannya dalam waktu yang tidak terlalu lama dan paling lama 3 (tiga) tahun;

c. pekerjaan yang bersifat musiman; atau

d. pekerjaan yang berhubungan dengan produk baru, kegiatan baru, atau produk tambahan yang masih dalam percobaan atau penjajakan.

2. Perjanjian dapat diperpanjang atau diperbaharui.

3. Waktu perjanjian kerja paling lama 2 (dua) tahun;

4. Perpanjangan hanya boleh dilakukan 1 (satu) kali untuk jangka waktu 1 (satu) tahun;

5. Perpanjangan harus diberitahukan terlebih dahulu kepada pekerja paling lama 7 (tujuh) hari sebelum perjanjian berakhir;

6. Pembaharuan diadakan setelah tenggang waktu 30 (tiga puluh) hari;

7. Pembaharuan perjanjian hanya boleh dilakukan 1 (satu) kali dengan jangka waktu paling lama 2 (dua) tahun;

Jika syarat-syarat tersebut dilanggar oleh pengusaha maka demi hukum perjanjian kerja waktu tertentu atau karyawan kontrak berubah menjadi perjanjian kerja waktu tidak tertentu atau karyawan tetap, hal tersebut didasarkan pada Pasal 59 ayat (7) Jo. Pasal 57 ayat (2) Undang-Undang No. 13 Tahun 2003 tentang Ketenagakerjaan.

Pengaturan ini tidak berlaku terhadap tenaga kerja asing meskipun sudah diatur dalam Pasal 59 ayat (7) Jo. Pasal 57 ayat (2) Undang-Undang No. 13 Tahun 2003 tentang Ketenagakerjaan, karena terhadap tenaga kerja asing terikat oleh Pasal 42 ayat (4) UndangUndang Nomor 13 Tahun 2003 tentang Ketenagakerjaan, yaitu tenaga kerja asing dapat dipekerjakan di Indonesia hanya dalam hubungan kerja untuk jabatan tertentu dan waktu tertentu, yang menjadi dasar kenapa tenaga kerja asing tetap berstatus perjanjian kerja waktu tertentu dapat mengenyampingkan aturan Pasal 59 ayat (7) Jo. Pasal 57 ayat (2) UndangUndang No. 13 Tahun 2003 tentang Ketenagakerjaan.

Kasus yang pernah terjadi dalam hal tenaga kerja asing dipekerjka dengan perjanjian kerja waktu tertentu yaitu dalam Putusan Pengadilan Hubungan Industrial pada Pengadilan 
Negeri Jakarta Pusat Nomor 274/Pdt.Sus-PHI/2015/PN.JKT.PST tanggal 14 April $2016^{20}$ Jo. Putusan Mahkamah Agung Nomor: 697 K/Pdt. Sus-PHI/2016 tanggal 15 September 2016, dengan para pihak LAU CHAK LOONG, warga negara Malaysia sebagai Pemohon Kasasi/Penggugat melawan PT. WIRA PAMUNGKAS PARIWARA sebagai Termohon Kasasi/ Tergugat.

Penggugat mengajukan gugatan terhadap Tergugat karena dalam perjanjian kerja antara Penggugat dengan Tergugat tidak mengatur jangka waktu perjanjian kerja, dibuat dan ditandatngani dalam bahasa Inggris tanpa adanya terjemahan bahasa Indonesia, dan telah dijalani oleh Penggugat untuk masa kerja lebih dari 4 (empat) tahun, sehingga berdasarkan Pasal 59 ayat (7) Jo. Pasal 57 ayat (2) Undang-Undang No. 13 Tahun 2003 tentang Ketenagakerjaan perjanjian kerja waktu tertentu berubah menjadi perjanjian kerja waktu tidak tertentu.

Dalam persidangan di Pengadilan Hubungan Industrial pada Pengadilan Negeri Jakarta Pusat terbukti apa yang didalilkan oleh Penggugat, namun Majelis Hakim mengenyampingkan Pasal 59 ayat (7) Jo. Pasal 57 ayat (2) Undang-Undang No. 13 Tahun 2003 tentang Ketenagakerjaan, karena terdapat Pasal 42 ayat (4) Undang-Undang Nomor 13 Tahun 2003 tentang Ketenagakerjaan yang menyatakan bahwa tenaga kerja asing hanya dapat dipekerjakan dengan status perjanjian kerja waktu tertentu, kemudian Penggugat mengajukan upaya hukum kasasi, namun Mahkamah Agung pun menolak Kasasi Penggugat/ Pemohon Kasasi dan menguatkan Putusan Pengadilan Hubungan Industrial pada Pengadilan Negeri Jakarta Pusat. ${ }^{21}$

Dalam hal ini meskipun perusahaan mempekerjakan tenaga kerja asing dengan perjanjian kerja waktu tertentu, dan didalamnya terdapat pelanggaran yang seharusnya merubah sistem kerja tenaga kerja asing tersebut menjadi perjanjian kerja waktu tidak tertentu, namun karena adanya Pasal 42 ayat (4) Undang-Undang Nomor 13 Tahun 2003 tentang Ketenagakerjaan, maka tenaga kerja asing tersebut statusnya tetap dalam perjanjian kerja waktu tertentu.

Permasalahan diatas terjadi jika perusahaan tidak menginginkan tenaga kerja asing menjadi karyawan tetap, dampak lainnya jika perusahaan menginginkan tenaga kerja asing dipekerjakan dengan waktu tidak tertentu, hal tersebut dapat dilakukan oleh perusahaan karena tidak ada sanksi apapun bagi perusahaan dalam mempekerjakan tenaga kerja asing

\footnotetext{
${ }^{20}$ Lau Chak Loong V. PT. Wira Pamungkas Pariwara, Nomor 274/Pdt.Sus-PHI/2015/PN.JKT.PST, Pengadilan Hubungan Industrial pada Pengadilan Negeri Jakarta Pusat, 14 April 2016.

${ }^{21}$ Lau Chak Loong V. PT. Wira Pamungkas Pariwara, Nomor: 697 K/Pdt. Sus-PHI/2016, Mahkamah Agung RI, 15 September 2016.
} 
meskipun hal tersebut sebenarnya dilarang oleh Pasal 42 ayat (4) Undang-Undang Nomor 13 Tahun 2003 tentang Ketenagakerjaan.

Sehingga yang terjadi seolah-olah tidak ada aturan yang mengatur perusahaan dalam mempekerjakan tenaga kerja asing berapa lamapun jangka waktunya selama perusahaan menghendaki. Sehingga tidak ada keseimbangan kedudukan antara perusahaan dengan tenaga kerja asing yang akan dipekerjakan. Oleh karena itu, seharusnya apabila terdapat posisi yang tidak seimbang di antara para pihak, maka hal ini harus ditolak karena akan berpengaruh terhadap substansi maupun maksud dan tujuan dibuatnya kontrak tersebut. ${ }^{22}$

Perjanjian kerja tenaga kerja asing ini disatu sisi pengaturannya sangat rumit, para pihak yang membuat perjanjian harus tunduk dan patuh terhadap aturan Undang-Undang Nomor 13 Tahun 2003 tentang Ketenagakerjaan, disisi lain Undang-Undang Nomor 13 Tahun 2003 tentang Ketenagakerjaan saling bertentangan antara Pasal 59 ayat (7) Jo. Pasal 57 ayat (2) yang harus merubah status perjanjian kerja waktu tertentu menjadi perjanjian kerja waktu tidak tertentu dengan Pasal 42 ayat (4) yang melarang mempekerjakan tenaga kerja asing dengan perjanjian kerja waktu tidak tertentu. Sehingga Undang-Undang Nomor 13 Tahun 2003 tentang Ketenagakerjaan tidak memiliki kepastian hukum. Menurut Sudikno Mertokusumo $^{23}$ kepastian hukum merupakan sebuah jaminan bahwa hukum tersebut harus dijalankan dengan cara yang baik. Kepastian ukum menghendaki adanya upaya pengaturan hukum dalam perundang-undangan yang dibuat oleh pihak yang berwenang. Sehingga aturan-aturan itu memiliki aspek yuridis yang dapat menjamin adanya kepastian bahwa hukum berfungsi sebagai suatu peraturan yang harus ditaati.

Jika dikaitkan dengan asas kebebasan berkontrak, seperti pembahasan awal diatas yang berarti setiap orang bebas untuk mengadakan suatu perjanjian yang memuat syaratsyarat perjanjian macam apapun, sepanjang perjanjian itu dibuat secara sah dan beritikad baik, serta tidak melanggar ketertiban umum dan kesusilaan.

Maka berdasarkan asas kebebasan berkontrak apabila pengusaha dengan tenaga kerja asing ingin membuat perjanjian kerja diberikan kebebasan mengatur klausul perjanjian tersebut sepanjang syarat sah perjanjian yang diatur dalam Pasal 1320 KUHPerdata terpenuhi, yaitu adanya kata sepakat, cakap mereka yang membuat perjanjian, adanya objek

\footnotetext{
22 Agus Yudha, Hukum Perjanjian, Asas Proporsionalitas Dalam Kontrak Komersial, (Jakarta: Kencana Prenada Media Group, 2010), 84.

${ }^{23}$ Sudikno Mertokusumo, Penemuan Hukum, (Yogyakarta: Liberty 2009) 21.
} 
yang diperjanjikan dan sebab yang halal yang tidak melanggar ketertiban umum, kesusilaan dan perundang-undangan. ${ }^{24}$

Maka dalam perjanjian kerja tidak boleh bertentangan dengan Undang-Undang Nomor 13 Tahun 2003 tentang Ketenagakerjaan, namun yang menjadi permasalahan adalah pengaturan perjanjian tenaga kerja asing dalam Undang-Undang Nomor 13 Tahun 2003 tentang Ketenagakerjaan saling bertentangan, dalam Pasal 42 ayat (4) tenaga kerja asing hanya dapat dipekerjakan dengan status perjanjian kerja waktu tertentu, dan disisi lain jika perusahaan yang mempekerjakan tenaga kerja asing melakukan pelanggaran perjanjian kerja waktu tertentu, maka berdasarkan Pasal 59 ayat (7) Jo. Pasal 57 ayat (2) demi hukum perjanjian kerja waktu tertentu tersebut berubah menjadi perjanjian kerja waktu tidak tertentu, namun Kembali lagi terbentu Pasal 42 ayat (4) tenaga kerja asing hanya dapat dipekerjakan dengan status perjanjian kerja waktu tertentu.

Maka pada akhirnya pengusaha dengan tenaga kerja asing dapat mengatur apapun yang disepakati oleh para pihak selama syarat sah perjanjian Pasal 1320 KUHPerdata terpenuhi. Dasar acuan oleh pengusaha dengan tenaga kerja asing dalam menjalankan hubungan industrialnya adalah perjanjian tersebut sebagaimana diatur Pasal 1338 ayat (1) KUHPerdata, yang menyatakan bahwa semua kotrak/perjanjian yang dibuat secara sah berlaku sebagai undang-undang bagi mereka yang membuatnya. Sehingga asas kebebasan berkontrak dalam membuat perjanjian kerja tenaga kerja asing dapat diterapkan, yaitu para pihak dapat mengatur klausul serta syarat-syarat apapun dalam perjanjian kerja, selama syarat sah perjanjian Pasal 1320 KUHPerdata terpenuhi. Apabila merujuk kepada Pasal 1320 KUHPerdata, sebenarnya terdapat beberapa persyaratan yang membatasi penerapan asas kebebasan berkontrak sesuai dengan persyaratan sahnya perjanjian, ${ }^{25}$ yaitu syarat subjektif, sepakat mereka yang melakukan perjanjian, dan cakap, selain syarat subjektif yaitu syarat objektif, yaitu adanya hal tertentu yang diperjanjikan, dan karena sebab yang halal.

Sehingga menjadi batasan terhadap asas kebebasan berkontrak ketika memenuhi syarat sah perjanjian tentang sebab yang halal yaitu tidak bertentangan dengan perundangundangan. ${ }^{26}$ Namun dalam perjanjian kerja tenaga kerja asing jika mengacu kepada UndangUndang Nomor 13 Tahun 2003 tentang Ketenagakerjaan masih dapat dilakukan sebebasbebasnya selama pengusaha dengan tenaga kerja asing sepakat, namun lain cerita jika

\footnotetext{
${ }^{24}$ Maria Anggita Dian Pramestie, Jamal Wiwoho, "Implementasi Asas Kebeasan Berkontrak Dalam Perjanjian Pemberian Kredit”, Jural Repertorium, Vol. IV No. 2 (2017): 110-111.

${ }^{25}$ Ridwan Khairandy, Hukum Kontrak Indonesia Dalam Perspektif Perbandingan, (Yogyakarta, FH UII Press, 2013), 89.

${ }^{26}$ Novi Ratna Sari, "Komparasi Syarat Sah Nya Perjanjian Menurut Kitab Undang-Undang Hukum Perdata Dan Hukum Islam”, Jurnal Repertorium Vol. IV. No. 2 (2017): 79-84.
} 
ISSN (Print): 2085-8477; ISSN (Online): 2655-4348

Undang-Undang Nomor 13 Tahun 2003 tentang Ketenagakerjaan dilakukan revisi pengaturan kaitan dengan pengaturan penggunaaan tenaga kerja asing. Sehingga terhadap asas kebebasan berkontrak tidak dapat diterapkan bebas tanpa ada batasan, yang dapat membatasi asas kebebasan berkontrak yaitu negara melalui peraturan perundang-undangan.

Hal tersebut dapat dipandang dua arah, yaitu undang-undang sebagai saran untuk membatasi kekuasaan penguasa dengan bersaranakan hukum pembatasan ini menjadi penting untuk mengimbangi kewenangan yang diberikan kepada pemerintah untuk ikut serta/campur tangan dalam kehidupan pribadi.

Pembatasan ini bertujuan untuk mencegah penguasa melanggar hak-hak individu, sedangkan sarana yang membatasi campur tangan negara pada kehidupan individu diatur dalam Undang-Undang. ${ }^{27}$ Undang-Undang merupakan landasan keabsahan campur tangan negara dalam kehidupan pribadi, diluar kewenangan yang diberikan oleh Undang-Undang dianggap sebagai suatu pelanggaran dalam kehidupan pribadi.

\section{PENUTUP}

Perjanjian kerja tenaga kerja asing yang diatur dalam Undang-Undang Nomor 13 Tahun 2003 tentang Ketenagakerjaan tidak mencerminkan kepastian hukum, yaitu dalam Pasal 42 ayat (4) tenaga kerja asing hanya dapat dipekerjakan dengan status perjanjian kerja waktu tertentu, dan disisi lain jika perusahaan yang mempekerjakan tenaga kerja asing melakukan pelanggaran perjanjian kerja waktu tertentu, maka berdasarkan Pasal 59 ayat (7) Jo. Pasal 57 ayat (2) demi hukum perjanjian kerja waktu tertentu tersebut berubah menjadi perjanjian kerja waktu tidak tertentu, namun Kembali lagi terbentur Pasal 42 ayat (4) tenaga kerja asing hanya dapat dipekerjakan dengan status perjanjian kerja waktu tertentu.

Akibat hukum jika Pasal 57 ayat (1) dan Pasal 59 Undang-Undang Nomor 13 Tahun 2003 tentang Ketenagakerjaan dilanggar oleh perusahaan adalah perjanjian kerja waktu tertentu atau karyawan kontrak demi hukum berubah menjadi perjanjian kerja waktu tidak tertentu atau karyawan tetap, namun hal ini bertentangan dengan Pasal 42 ayat (4) UndangUndang Nomor 13 Tahun 2003 tentang Ketenagakerjaan, yang mengharuskan tenaga kerja asing hanya dapat dipekerjakan dengan sistem perjanjian kerja waktu tertentu, yang berakibat lex specialis dalam pengaturan tenaga kerja asing yaitu Undang-Undang No. 13 Tahun 2003 tentang Ketenagakerjaan tidak mengikat kepada tenaga kerja asing selama perusahaan

${ }^{27}$ Hotma P. Sibue, Asas Negara Hukum, Peraturan Kebijakan \& Asas-Asas Umum Pemerintahan yang Baik, Jakarta: Erlangga, 2010) 32. 
menghendaki untuk mempekerjakan tenaga kerja asing dengan syarat macam apapun, sehingga yang perlu diperhatikan yaitu dalam menerapkan asas kebebasan berkontrak dalam membuat perjanjian tenaga kerja asing, para pihak diberikan kebebasan untuk mengatur isi klausul dari perjanjian tersebut selama syarat sah perjanjian dalam Pasal 1320 KUHPerdata terpenuhi, yaitu sepakat, cakap, hal tertentu dan sebab yang halal. Sebab yang halal artinya klausul perjanjian tersebut tidak boleh bertentangan dengan ketertiban umum, kesusilaan dan perundang-undangn, perundang-undangan dimaksud disini yaitu Undang-Undang Nomor 13 Tahun 2003 tentang Ketenagakerjaan, namun Undang-Undang Nomor 13 Tahun 2003 tentang Ketenagakerjaan pengaturannya terdapat ketidakpastian, yang pada akhirnya dikembalikan kepada para pihak yang membuat perjanjian. Sehingga terhadap asas kebebasan berkontrak ini negara hanya bisa mengatur isi perjanjian para pihak tersebut melalui undang-undang yang dapat diaplikasikan oleh para pihak.

\section{DAFTAR PUSTAKA}

Agus Yudha, Hukum Perjanjian, Asas Proporsionalitas Dalam Kontrak Komersial, Jakarta: Kencana Prenada Media Group, 2010.

Ahmadi Miru, Hukum Kontrak \& Perancangan Kontrak, Jakarta: PT Rajagrafindo Persada, 2011.

Aries Harianto, Hukum Ketenagakerjaan Makna Kesusilaan dalam Perjanjian Kerja, Yogyakata: Lakbang PRESSindo, 2016.

Danang Sunyoto, Hak dan Kewajiban bagi Pekerja dan Pengusaha, Jakarta: Pustaka Yustisia, 2013.

Hotma P. Sibue, Asas Negara Hukum, Peraturan Kebijakan \& Asas-Asas Umum Pemerintahan yang Baik, Jakarta: Erlangga, 2010.

Johnny Ibrahim, Teori dan Metodologi Penelitian Hukum Normatif, Malang: Bayumedia Publishing, 2007.

Ridwan Khairandy, Itikad Baik Dalam Kebebasan Berkontrak, Jakarta, Fakultas Program Pascasarjana Fakultas Hukum Universitas Indonesia, 2003.

Ridwan Khairandy, Hukum Kontrak Indonesia Dalam Perspektif Perbandingan, Yogyakarta: FH UII Press, 2013.

Sudikno Mertokusumo, Penemuan Hukum, Yogyakarta: Liberty, 2009.

Anis Tiana Pottag, "Politik Hukum Pengendalian Tenaga Kerja Asing Yang Bekerja Di Indonesia”, Media Iurius, Vol. 1 No. 2 (2018): 236-237.

Muhammad Noor, "Penerapan Prinsip-Prinsip Hukum Perikatan Dalam Pembuatan Kontrak”, Mazahib Jurnal Pemikiran Hukum Islam, Vol. XIV No. 1 (2015): 8991. 
ISSN (Print): 2085-8477; ISSN (Online): 2655-4348

Maria Anggita Dian Pramestie, Jamal Wiwoho, "Implementasi Asas Kebeasan Berkontrak Dalam Perjanjian Pemberian Kredit”, Jural Repertorium Vol. IV No. 2, (2017): 110-111.

Dedi Harianto, “Asas Kebebasan Berkontrak: Problematika Penerapannya Dalam Kontrak Baku Antara Konsumen Dengan Pelaku Usaha”, Jurnal Hukum Samudra Keadilan, Vol. II Nomor 2 (2016): 145-149.

Gios Adhyaksa, "Penerapan Asas Perlindungan Yang Seimbang Menurut Kuhperdata Dalam Pelaksanaan Perjanjian Kerja Untuk Waktu Tertentu Dihubungkan Dengan Undang-Undang Nomor 13 Tahun 2003 Tentang Ketenagakerjaan”, Jurnal Unifikasi,Vol. 3 No. 2 (2016): 77-81.

Falentino Tampongangoy, "Penerapan Sistem Perjanjian Kerja Waktu Tertentu Di Indonesia “,Lex Privatum Vol. I No. 1 (2013): 146-154.

Risky Vista Puspita Sari, Aries Harianto, Ida Bagus Oka Ana, "Kepastian Hukum Pengaturan Penggunaan Tenaga Kerja Asing di Indonesia”, Lentera Hukum Vol. 5 Issue 3 (2018): 368-374.

Maria Anggita Dian Pramestie, Jamal Wiwoho, "Implementasi Asas Kebeasan Berkontrak Dalam Perjanjian Pemberian Kredit”, Jural Repertorium, Vol. IV No. 2 (2017): 110-111.

Novi Ratna Sari, "Komparasi Syarat Sah Nya Perjanjian Menurut Kitab Undang-Undang Hukum Perdata Dan Hukum Islam”, Jurnal Repertorium Vol. IV. No. 2 (2017): 79- 84.

Lau Chak Loong V. PT. Wira Pamungkas Pariwara, Nomor 274/Pdt.SusPHI/2015/PN.JKT.PST, Pengadilan Hubungan Industrial pada Pengadilan Negeri Jakarta Pusat, 14 April 2016.

Lau Chak Loong V. PT. Wira Pamungkas Pariwara, Nomor: 697 K/Pdt. Sus PHI/2016, Mahkamah Agung RI, 15 September 2016.

Undang-Undang Nomor 13 Tahun 2003 tentang Ketenagakerjaan, Republik Indonesia, 2003. 